\title{
Calcareous nannofossil, ostracode and foraminifera biostratigraphy of Plio-Pleistocene deposits, Rhodes (Greece), with a correlation to the Vrica section (Italy)
}

\author{
ERIK THOMSEN ${ }^{1}$, TINE L. RASMUSSEN ${ }^{2}$ \& ANNETTE HASTRUP ${ }^{3}$ \\ ${ }^{1}$ Department of Earth Sciences, University of Aarhus, C. F. Møllers Allé, DK-8000 Århus C, Denmark. \\ ${ }^{2}$ Department of Quaternary Geology, Lund University, Tornavägen 13, S-223 63 Lund, Sweden. \\ ${ }^{3}$ Roskilde Amt, Teknisk Forvaltning, Køgevej 80, DK-4000 Roskilde, Denmark.
}

\begin{abstract}
The Kalithea Bay section is situated on the southeastern coast of the island of Rhodes. The section comprises a sedimentary sequence ranging from brackish water gravel and nearshore sand to deep-water clay. The brackish water and nearshore deposits are assigned to the Kritika Formation, while the deep-water deposits are assigned to the Lindos Bay clay. Calcareous nannofossil biostratigraphy shows that the age of the marine sequence is Early Pleistocene. The brackish water sediments cannot be dated with any degree of certainty. The marine deposits are rich in ostracodes and foraminifera and several species have been recognized, which previously have been used as biostratigraphic markers in the Plio-Pleistocene deposits of Rhodes. Biostratigraphic correlation between the Kalithea Bay section and the Plio-Pleistocene boundary stratotype at Vrica, southern Italy, shows that the ostracodes and foraminifera events generally are diachronous relative to the calcareous nannofossil events. The only exception is the first occurrence of the benthic foraminifera Hyalinea balthica. As calcareous nannofossil events are thought to be virtually synchronous within the Mediterranean region, it is concluded that the diachroneity is due to a relative delay in the appearance of ostracodes and foraminifera at Kalithea, caused by differences in the palaeobathymetric settings between the two sites. J. Micropalaeontol. 20(2): 143-154, December 2001.
\end{abstract}

\section{INTRODUCTION}

The island of Rhodes is situated in the southeastern Aegean Sea on the southern rim of the Anatolian plate in an active tectonic regime (Fig. 1). Plio-Pleistocene beds, known for their rich faunas and floras, occur scattered over large parts of the island, with marine facies particularly well developed along the southeast coast (Mutti et al., 1970; Meulenkamp et al., 1972; Hanken et al., 1996; Fig. 2a). The Plio-Pleistocene sediments range from fluviatile gravel to upper slope clay, and it is characteristic that sediments representing widely different environments may be found in close succession within a single outcrop. The fossil and sedimentary records indicate that the island, during this time period, underwent complex geological changes, involving considerable sinking and uplift.

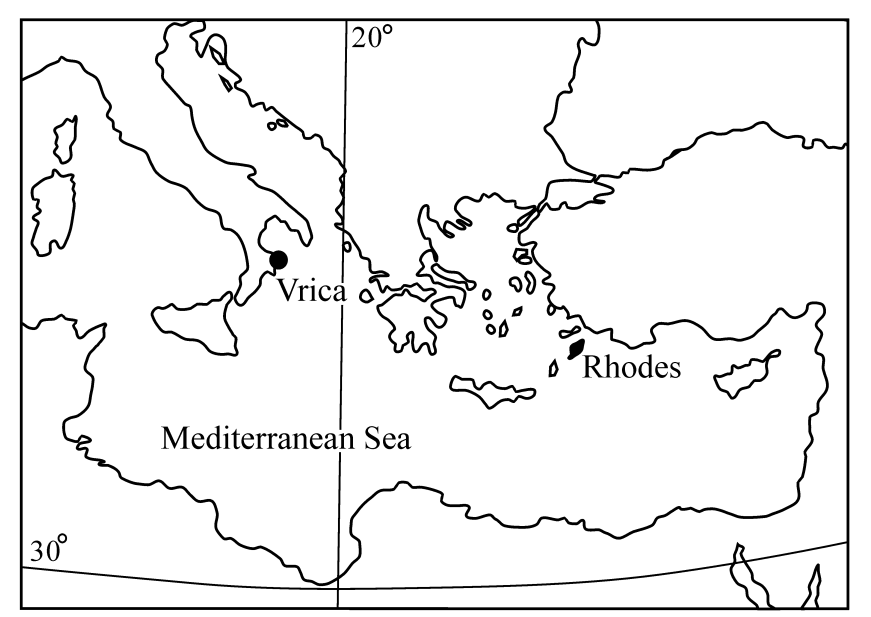

Fig. 1. Map of the Mediterranean Sea showing the position of the island of Rhodes and the Plio-Pleistocene boundary stratotype at Vrica.
However, the palaeoenvironmental information retained in the Plio-Pleistocene deposits has not been fully exploited so far, due to a severe lack of biostratigraphic data (Hanken et al., 1996). The deposits are patchily preserved in small, isolated basins, all with slightly different geological histories, and facies shifts, both vertically and horizontally, are often extremely rapid. Without good age determinations and reliable biostratigraphic correlations our understanding of the history of the island can only be very incomplete.

Previous biostratigraphic studies on the Plio-Pleistocene deposits of Rhodes have been based mainly on benthic foraminifera and ostracodes (e.g. Orombelli \& Montanari, 1967; Sissingh, 1972; Mostafawi, 1989a) and the stratigraphic ranges of taxa of these groups are often controlled by environmental factors. Only a few Mediterranean species can be regarded as reliable biostratigraphic markers (Sprovieri \& Hasegawa, 1990). Moreover, the better known markers from the western Mediterranean have rarely been found on Rhodes.

The main purpose of the present study is to determine the age of a Plio-Pleistocene sequence exposed at Kalithea Bay, northeast Rhodes, and to introduce a more dependable biostratigraphic tool for future work on the island. To attain that goal, we have studied calcareous nannofossils, as well as ostracodes and foraminifera. Calcareous nannofossils were selected because several studies of Pliocene and Pleistocene deposits from various parts of the Mediterranean region have shown that this group provides a reliable biostratigraphic framework with a very high stratigraphic resolution (e.g. Raffi \& Rio, 1979; Rio et al., 1990; de Keanel et al., 1999). Foraminifera and ostracodes were selected because they traditionally have been used for age determinations and correlations on Rhodes. In order to compare and evaluate the results of the ostracodes and foraminifera relative to those of the calcareous nannofossils, we correlate the 


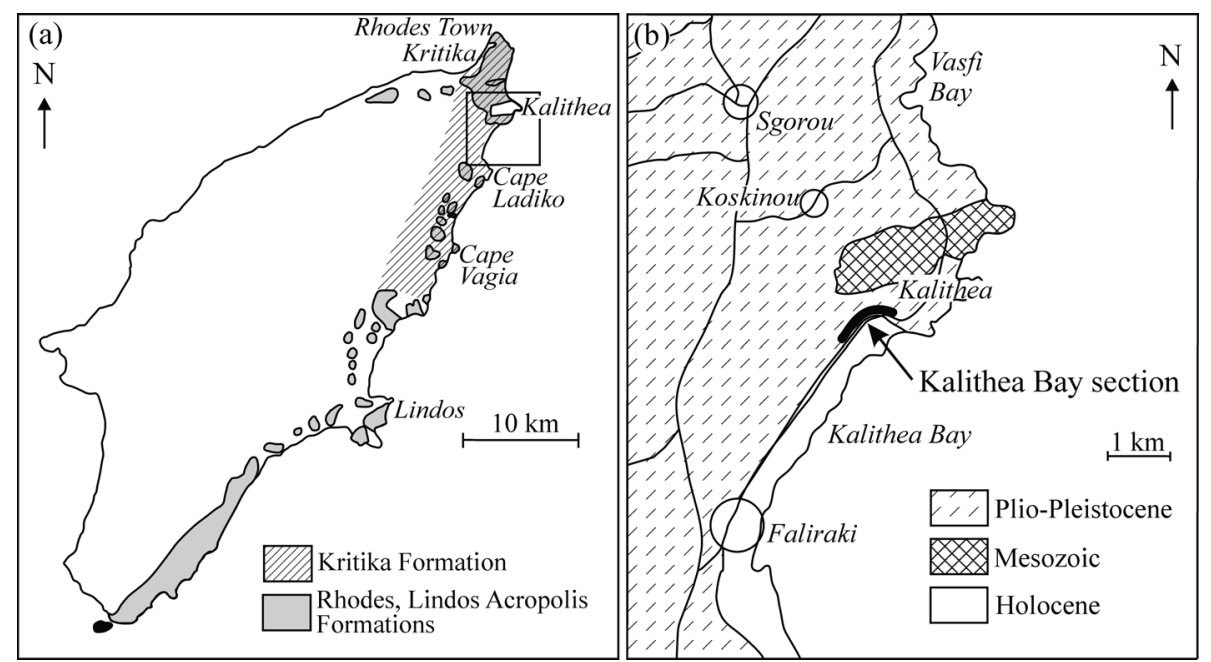

Fig. 2. (a) Map of the island of Rhodes showing the approximate present distribution of the Plio-Pleistocene Kritika, Rhodes, and Lindos Acropolis formations (after Meulenkamp et al., 1972 with modifications after Hanken et al., 1996). Framed area shown in detail in (b). (b). Simplified geological map of the northern part of the Kalithea Bay area and the Kalithea Peninsula, northeastern Rhodes, showing the position of the Kalithea Bay section and the distribution of Plio-Pleistocene deposits in the area. Mesozoic basement limestone is outcropping just north of the section.

Kalithea Bay section with the Plio-Pleistocene boundary stratotype at Vrica, Italy, where all three groups have also been studied.

\section{LITHOSTRATIGRAPHY AND CHRONOSTRATIGRAPHY OF THE PLIO-PLEISTOCENE DEPOSITS ON RHODES}

The Miocene and Early Pliocene deposits on Rhodes consist of thick packages of fluvio-lacustrine sediments delivered by rivers from the Asiatic mainland, to which the island at that time was connected (Meulenkamp et al., 1972). During the latest Pliocene and Early Pleistocene, the island was separated from Asia and partly submerged, and a highly variable succession of brackish water and marine deposits overlies the terrestrial sediments. The marine deposits are particularly well developed along the east coast, where they are referred to three formations (Hanken et al., 1996; Figs. 2a, 3).

The deposits of the Kritika Formation vary from coarsegrained, siliciclastic sediments to strongly fossiliferous limestones. They were deposited in mixed paralic and nearshore environments (Meulenkamp et al., 1972; Hanken et al., 1996). The formation is up to $180 \mathrm{~m}$ thick, but the thickness is highly variable. The Kritika Formation has been referred to the Late Pliocene on the basis of ostracodes (Sissingh, 1972) and sporomorphs (Benda et al., 1977).

The overlying Rhodes Formation is separated from the Kritika Formation by an erosional unconformity, according to Hanken et al. (1996). These authors subdivided the Rhodes Formation into a number of facies groups (Fig. 3), but most of these have only been observed south of Ladiko, particularly in the Lindos area (Fig. 2a). To the north, in the Kalithea area, the Rhodes Formation is represented only by the Lindos Bay clay and the Cape Arkhangelos calcarenite (Hansen, 1999; Fig. 3). The Lindos Bay clay (equal to the Vasfi Formation of Meulenkamp et al., 1972) is blue-grey, silty, clay up to $30 \mathrm{~m}$ thick, with a characteristic fauna of deep-water bryozoans and pteropods, and it was probably deposited at a considerable

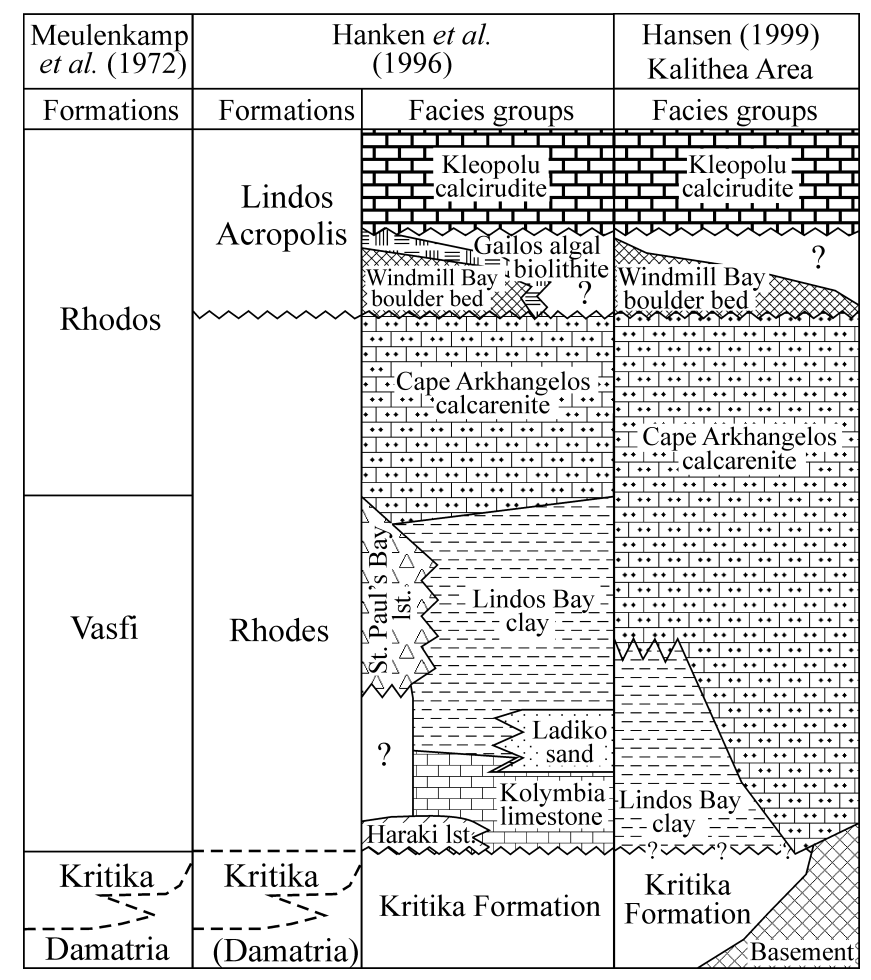

Fig. 3. Lithostratigraphic subdivision of the Plio-Pleistocene deposits on Rhodes. The subdivision proposed by Meulenkamp et al. (1972) has been used in several older biostratigraphic works from the island, e.g. Sissingh (1972). Hanken et al. (1996) based their revised subdivision on precise type localities, and they were able to subdivide some of their formations into a number of facies groups, based mainly on observations in the Ladiko and Lindos areas. Hansen (1999) proposed a simplified version for the Kalithea area, where several of the facies groups recognized to the south by Hanken et al. (1996) are not present. Diagram based on Hanken et al. (1996) and Hansen (1999). 
water depth, possibly $300-500 \mathrm{~m}$ or more (Moissette \& Spjeldnæs, 1995; Spjeldnæs \& Moissette, 1997; Kovacs \& Spjeldnæs, 1999). Sissingh (1972) and Benda et al. (1977) indicated that the Plio-Pleistocene boundary was situated within the Vasfi Formation (equal to the Lindos Bay clay).

The Lindos Bay clay is unconformably draped by the Cape Arkhangelos calcarenites (Fig. 3). This facies group consists of bioclastic limestones often forming large clinoform beds (Hanken et al., 1996; Hansen, 1999). The Cape Arkhangelos calcarenite was interpreted as a beach-rock or 'panchina' by Mutti et al. (1970), and it rapidly increases in thickness from zero to about $50 \mathrm{~m}$ in a seaward direction.

The uppermost of the Pleistocene facies groups on Rhodes are included in the Lindos Acropolis Formation (Hanken et al., 1996; Fig. 3). This formation is less than $18 \mathrm{~m}$ thick and consists of very coarse limestones, partly reworked from older formations. The limestones were deposited in a high-energy, near-coast environment (Hanken et al., 1996).

\section{THE KALITHEA BAY SECTION}

The investigated section is located about $12 \mathrm{~km}$ southeast of Rhodes Town in the northern part of a coastal basin bounded by the peninsula of Kalithea to the north and Cape Ladiki to the south (Fig. 2b). The section is $380 \mathrm{~m}$ long and reaches a stratigraphic thickness of approximately $30 \mathrm{~m}$, with the base about $7 \mathrm{~m}$ above sea level (Fig. 4). Lithologically, the section can be subdivided into 24 distinct units.

\section{Lithology and depositional environment}

The lowermost $11 \mathrm{~m}$ (units 1-13) consist of alternating beds of gravel, sand and silt (Fig. 4). Unit 1 probably represents a fluviatile environment, while the remaining units 2-13 were deposited in brackish water, lagoonal environments, as indicated by a scattered fauna of brackish water bivalves and gastropods. The upper units 14-24 contain a rich fauna of corals, bivalves, gastropods, brachiopods and bryozoans and were clearly deposited under fully marine conditions. The lower, fully marine, units $15-17$ are composed mainly of gravel and sand and they were obviously deposited in shallow water. Upwards, the thickness and the grain-size of the coarser beds decrease and the upper part of the section (units 19-24) is dominated by beds of silty clay (Fig. 4). The uppermost unit 24 contains bryozoans and abundant pteropods. The bryozoans seem quite similar to the bathyal faunas described from the Lindos Bay clay (Moissette \& Spjeldnæs, 1995), and the unit was probably deposited under bathyal conditions. Several, more or less distinctly, laminated beds intersect the upper part of the section indicating that parts of the sediments were deposited under anoxic conditions. The marly clay of unit 24 is, unconformably, overlain by a clastic calcarenite which, according to Hansen (1999), was deposited in a high-energy, shallow water environment.

Overall, the sequence of the Kalithea Bay section can be interpreted to reflect a large transgressive-regressive cycle, with unit 24 representing the deepest setting.

\section{Lithostratigraphy}

The lithology of the upper part of the Kalithea Bay section was studied by Hansen (1999, fig. 3B). He concluded that the topmost blue-grey clay (our unit 24) represented the Lindos Bay clay and that the overlying 'panchina' was a local, rather siliciclastic, development of the Cape Arkhangelos calcarenite (Fig. 4). The brackish water and nearshore facies constituting the lower part of the section show considerable similarity to the Kritika Formation and they most likely represent this formation. However, the exact position of the boundary between the Kritika Formation and the Lindos Bay clay is difficult to place. According to Hanken et al. (1996), the boundary is usually marked by severe erosion, but signs of such an event have not been observed in the Kalithea Bay section. Tentatively, we place the boundary between units 23 and 24 (Fig. 4).

\section{Material and methods}

Sixty-seven samples, each with a dry weight of 200-400 g, were examined for microfossils. The samples represent all units except for the strongly indurated 'panchina'. Eight samples were barren of microfossils and a total of 59 samples were analysed quantitatively for foraminifera, while 34 samples were analysed for ostracodes. Forty-two samples mainly from the marine part of the section were examined for calcareous nannofossils. Fourteen of these were barren.

\section{Micropalaeontological techniques}

The micropalaeontological samples were washed through a series of sieves using standard micropalaeontological methods. A total of $350-450$ specimens of ostracodes were picked from the $125-1000 \mu \mathrm{m}$ fraction. Foraminifera were picked from the $100-2000 \mu \mathrm{m}$ fraction. More than 500 benthic and about 300 planktic specimens were counted in each sample. The residues coarser than $2000 \mu \mathrm{m}$ were empty for both ostracodes and foraminifera.

The results of the quantitative study will be presented elsewhere. Here it should be noted that a total of approximately 300 species of benthic foraminifera and 200 species of ostracodes have been encountered.

\section{Calcareous nannofossil techniques}

The samples were analysed using both light microscopy and scanning electron microscopy (SEM). Standard nannofossil smear-slide techniques were used to prepare the samples. Taxon identification was mainly performed using light microscopy at a magnification of $\times 1250$. Size measurements of Gephyrocapsa spp., Crenalithus spp. and Calcidiscus spp. were done using a CamScan MaXim 2040S scanning electron microscope. Abundance of taxa was only noted semi-quantitatively due to poor preservation and heavy dissolution in many samples.

\section{BIOSTRATIGRAPHY OF THE KALITHEA BAY SECTION}

\section{Calcareous nannofossil biostratigraphy}

Several biostratigraphic studies of the Pliocene and Pleistocene deposits in the Mediterranean region have shown that calcareous nannofossils provide a reliable tool for correlation with a very high stratigraphic resolution (e.g. Schmidt, 1973; Müller, 1978, 1990; Ellis \& Lohman, 1979; Raffi \& Rio, 1979; Rio et al., 1990; Di Stefano \& Sprovieri, 1990; Castradori, 1993; 


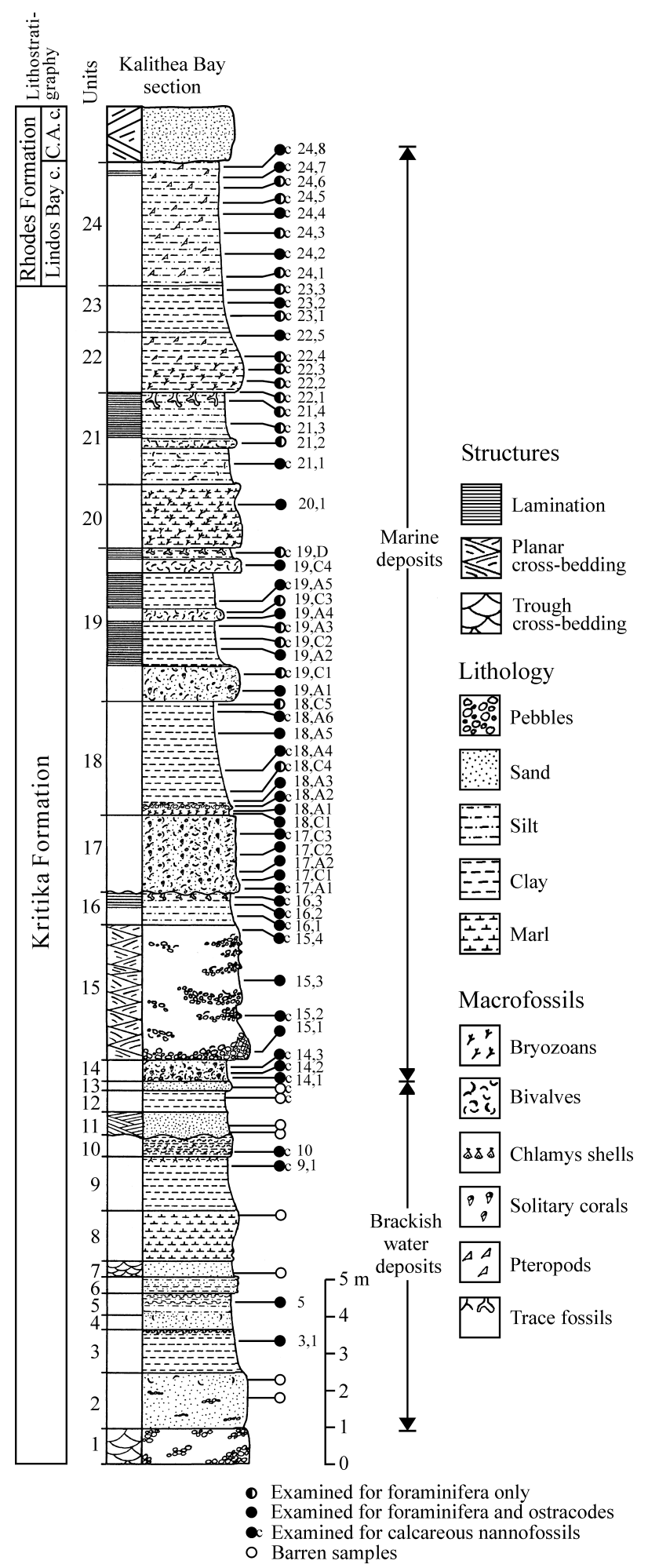

Fig. 4. Composite log showing lithology, sedimentary structures, macrofossil content and sample position of the Kalithea Bay section. The exposure is an approximately $380 \mathrm{~m}$ long road cut and the lower units $1-18$ of the section were measured in the southern and central part of the profile, while the upper units 19-24 were measured in the northern part. The strongly indurated Cape Arkhangelos calcarenite was not sampled. Abbreviations: Lindos Bay c, Lindos Bay clay; C.A.c, Cape Arkhangelos calcarenite.
Di Stefano, 1998; Staeker, 1998; de Keanel et al., 1999). Furthermore, recently, most of the Late Pliocene to Pleistocene calcareous nannofossil datum events have been calibrated to the astronomically controlled sapropel patterns observed at several localities throughout the Mediterranean region (e.g. Lourens et al., 1996, 1998; de Keanel et al., 1999). The calibrations indicate that the calcareous nannofossil events are virtually synchronous within the Mediterranean area, and they have made it possible to determine the ages of the biostratigraphic events with great precision (e.g. Lourens et al., 1996, 1998; de Keanel et al., 1999).

The position of the investigated samples and the distribution of calcareous nannofossils in the Kalithea Bay section are shown in Figure 5. Calcareous nannofossils were present in all marine beds except for some samples from the laminated sections of units 16, 19 and 21. They were common and fairly well preserved in the coarse-grained units 14,15 and 17 and in the silty clay of unit 24 , whereas they were rare and generally poorly preserved in the fine-grained units 18-23. Only a very small number of reworked specimens were encountered, including a few specimens of Late Cretaceous taxa and a few, heavily corroded, specimens of Sphenolithus sp. and Discoaster sp. Both of these genera vanished during the Late Pliocene.

The biostratigraphic interpretation and age assignment of the Kalithea Bay section is shown in Figure 5. We have followed the zonation scheme proposed by Rio et al. (1990) for the Plio-Pleistocene deposits of the western and central Mediterranean. This scheme has proven applicable also for the eastern Mediterranean (Castradori, 1993; Staeker, 1998; Di Stefano, 1998). The ages of the nannofossil events defining the zonal boundaries and a few additional datum events are from de Keanel et al. (1999).

Units 14 and 15 are referred to zone MNN19c due to the presence of medium-sized gephyrocapsids between 5 and $5.5 \mu \mathrm{m}$ (P1. 1, fig. 3) and the absence of Calcidiscus macintyrei and large-sized gephyrocapsids $>5.5 \mu \mathrm{m}$ (Fig. 5). C. macintyrei is here taken as circular forms $>11 \mu \mathrm{m}$ and composed of more than 40 elements (cf. Raffi \& Rio, 1979; Backman \& Shackleton, 1983; Rio et al., 1990). Gephyrocapsids $>5.0 \mu \mathrm{m}$ appear in the Mediterranean almost simultaneously with the last occurrence of C. macintyrei (de Keanel et al., 1999). The event has been dated to $1.62 \mathrm{Ma}$ (de Keanel et al., 1999).

Unit 16 was barren of calcareous nannofossils. All samples from the base of unit 17 to the lower part of unit 23 (samples 17,1-23,1) contained gephyrocapsids $>5.5 \mu \mathrm{m}$ (Pl. 1, figs 4, 5) referring this interval to zone MNN19d. In the Mediterranean Sea, the first and last occurrences of gephyrocapsids $>5.5 \mu \mathrm{m}$ have been dated to $1.57 \mathrm{Ma}$ and $1.24 \mathrm{Ma}$, respectively (de Keanel et al., 1999). de Keanel et al. (1999) recognized several possible datum events within zone MNN19d. One of these, namely a marked increase in the abundance of Pseudoemiliania lacunosa (Pl. 1, figs 10, 11), was recognized in the Kalithea Bay section in sample 23,1. The age of this event was dated to 1.36 Ma by de Keanel et al. (1999). The uppermost part of the section, including samples $23,3-24,8$, is referred to zone MNN19e based on the presence of abundant gephyrocapsids $<3.5 \mu \mathrm{m}$ (Pl. 1, figs 1,2) and the absence of forms $>4.0 \mu \mathrm{m}$. Within this zone de Keanel et al. (1999) observed the first occurrence of Crenalithus asanoi, a circular form of Crenalithus 
Integrated microbiostratigraphy of the Plio-Pleistocene, Rhodes (Greece)

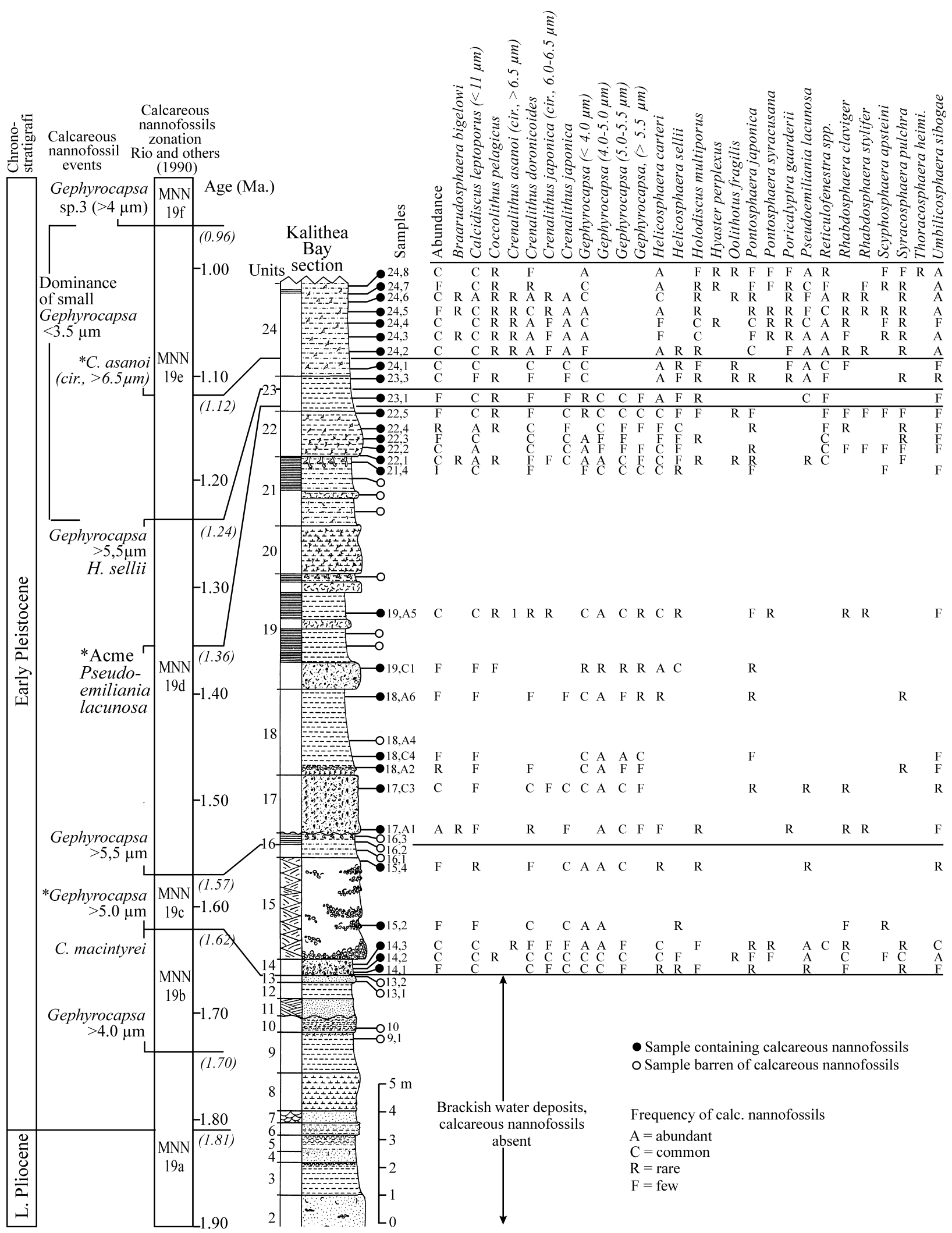

Fig. 5. Biostratigraphic zonation, age determination and distribution of calcareous nannofossils in the Kalithea Bay section, Rhodes. Zonation scheme and calcareous nannofossil events marking zonal boundaries are from Rio et al. (1990). Additional datum events marked by an asterisk (*) are from de Keanel et al. (1999). Ages of datum events are from de Keanel et al. (1999). The age of the Pliocene-Pleistocene boundary is from Lourens et al. (1996). 

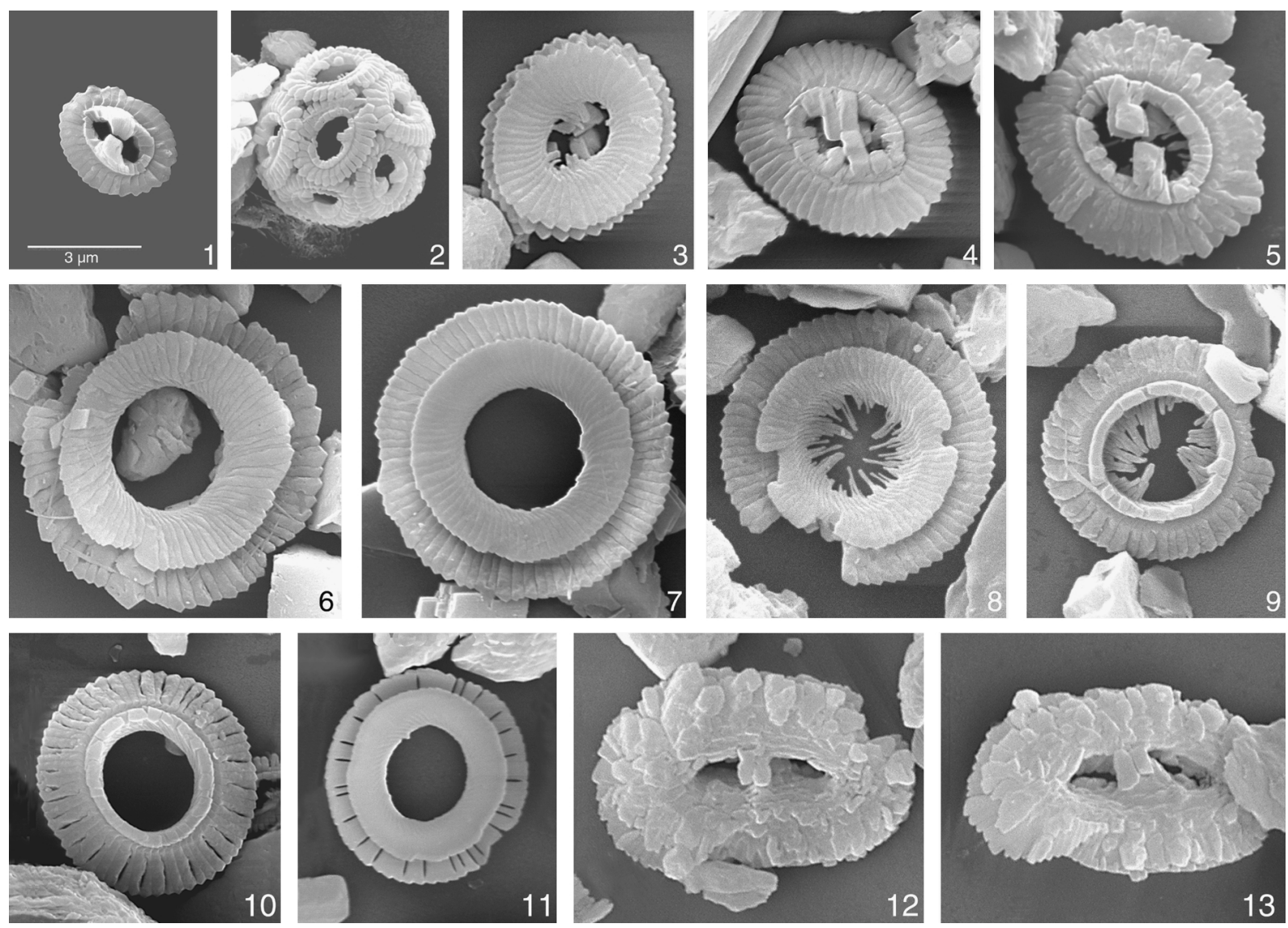

Explanation of Plate 1.

Stratigraphically important calcareous nannofossils from the Kalithea Bay section. All magnifications $\times 4800$. Bar scale $3 \mu$ m. Fig. 1. Gephyrocapsa, small-sized $(3.4 \mu \mathrm{m})$, distal view, sample 24,8. Fig. 2. Gephyrocapsa, small-sized (placolith size $2.7 \mu \mathrm{m}$ ), distal view, sample 24,4. Fig. 3. Gephyrocapsa, medium-sized $(5.5 \mu \mathrm{m})$, proximal view, sample 15,4. Fig. 4. Gephyrocapsa, large-sized $(5.7 \mu \mathrm{m})$, distal view, sample 17,C1. Fig. 5. Gephyrocapsa, large-sized $(6.9 \mu \mathrm{m})$, distal view, sample 22,5. Fig. 6. Crenalithus asanoi, (size $8.0 \mu \mathrm{m}$ ), proximal view, sample 24,2. Fig. 7. Crenalithus asanoi, proximal view, (size $7.7 \mu \mathrm{m}$ ), sample 24,4. Fig. 8. Crenalithus asanoi (size $7.1 \mu \mathrm{m}$ ), proximal view, sample 24,5. Fig. 9. Crenalithus japonica (size $5.8 \mu \mathrm{m}$ ), distal view, sample 24,5. Fig. 10. Pseudoemiliania lacunosa, distal view, sample 24,4. Fig. 11. Pseudoemiliania lacunosa, proximal view, sample 24,4. Fig. 12. Helicosphaera sellii, distal view, sample 22,5. Fig. 13. Helicosphaera sellii, distal view, sample 22,5. We have referred C. asanoi, C. japonica and C. doronicoides to the genus Ceralithus Roth 1973 in agreement with de Keanel et al. (1999). However, it should be noted that according to Young (1990) and Young \& Bown (1997) the holotype C. doronicoides (Black \& Barnes, 1961) is a junior synonym of Gephyrocapsa oceanica.

with a diameter $>6.5 \mu \mathrm{m}$ (Pl. 1, figs 6-8), which they dated to 1.12 Ma. We correlate this event to sample 24,2 in the Kalithea Bay section, where similar large forms were observed. However, it should be noted that a few specimens of $C$. asanoi were observed in unit 14, together with common Crenalithus japonica (Pl. 1, fig. 9). The first occurrence of $C$. asanoi may therefore be a slightly problematic event in the eastern Meditterranean and in need of further investigations.

The last calcareous nannofossil event in the Kalithea Bay section is the disappearance of Helicosphaera sellii (Plate 1, figs 12, 13) in sample 24,2 (Fig. 5). The last occurrence of $H$. selliihas often been recognized as a useful marker in the Mediterranean, generally coinciding with, or slightly predating, the last occurrence of gephyrocapsids $>5.5 \mu \mathrm{m}$ (Raffi \& Rio, 1979; Müller, 1990; Rio et al., 1990; Lourens et al., 1996, 1998; Di Stefano, 1998; de Keanel et al., 1999). However, the exact position of the event may be difficult to pinpoint as rare specimens may show up above the last consistent occurrence of the species, sometimes possibly due to reworking (Rio et al., 1990; de Keanel et al.,
1999). In order to establish a consistent event, Rio et al. (1990) defined the last occurrence of the $H$. sellii as the drop of the species below the $1 \%$ level. In the Kalithea Bay section no attempts were made to quantify the last appearance of $H$. sellii. The species is fairly common in the upper part of zone MNN19d, but it continues in low numbers into zone MNN19e and the last occurrence is above the appearance of C. asanoi. Thus, the last appearance of $H$. sellii in the Kalithea Bay section is slightly delayed as compared to the normal pattern in the Mediterranean. However, it should be noted that a sequence of events very similar to the one observed at Kalithea Bay has been reported from ODP site 953 in the eastern North Atlantic, southwest of the Gibraltar Strait (Sblendorio-Levy \& Howe, 1998).

In conclusion, the marine succession in the Kalithea Bay section (units 14-24) is referred to the Early Pleistocene. Accepting the ages calculated by de Keanel et al. (1999) for the calcareous nannofossil events in the Mediterranean Region, the basal bed of unit 14 is between $1.62 \mathrm{Ma}$ and $1.57 \mathrm{Ma}$ old 
Integrated microbiostratigraphy of the Plio-Pleistocene, Rhodes (Greece)

(Fig. 5). Considering that gephyrocapsids $>5.0 \mu \mathrm{m}$ occur in relatively high numbers in unit 14 (Fig. 5), an age of around 1.60 Ma seems most likely. The top of the investigated section is younger than $1.12 \mathrm{Ma}$ and older than $0.96 \mathrm{Ma}$, and the age is probably close to $1.00 \mathrm{Ma}$ (Fig. 5).

\section{Ostracode and foraminifera biostratigraphy}

Previous studies. Benthic foraminifera from the Plio-Pleistocene deposits of Rhodes have previously been studied by Orombelli \& Montanari (1967), who examined the foraminiferal faunas of the Vasfi Formation (Meulenkamp et al., 1972) (= Lindos Bay clay, see Fig. 3) and referred it to the Calabrian stage (Lower Pleistocene). Sissingh (1972, 1976, 1982) analysed a series of samples from the Kritika Formation, the Vasfi Formation and the Rhodes Formation (Meulenkamp et al., 1972) (= Lindos Acropolis Formation, see Fig. 3). Sissingh (1972) agreed with the dating of Orombelli \& Montanari (1967) of the Vasfi Formation, and assigned the Kritika Formation to the Late Pliocene. He also indicated that the Plio-Pleistocene boundary was situated within the Vasfi Formation. A similar position of the Plio-Pleistocene boundary was suggested by Løvlie et al. (1989) for the section at Cape Vagia on the basis of the occurrence of Hyalinea balthica and magnetostratigraphy. Ostracodes from the Damatria, Kritika and Vasfi formations have also been studied by Mostafawi (1989b). He placed the Damatria and Kritika formations in the Upper Pliocene and the Vasfi Formation in the Lower Pleistocene, in agreement with the results of Sissingh (1972). Other micropalaeontological studies have mainly been concerned with palaeoecological problems, e.g. Broekman (1973, 1974) and Hajjaji et al. (1998).

In this study we examine the biostratigraphic value of ostracodes and foraminifera by correlating the Kalithea Bay section to the Vrica section, southern Italy. This section has recently been approved as the stratotype for the Plio-Pleistocene boundary, and it has been studied in great detail for ostracodes and foraminifera, as well as calcareous nannofossils.

Biostratigraphic correlation between the Kalithea Bay section and the Pliocene-Pleistocene boundary stratotype at Vrica, Italy. Six biostratigraphic events of ostracodes and benthic and planktic foraminifera recognized in the stratotype for the PlioPleistocene boundary at Vrica, southern Italy, and often used for correlation purposes in the Mediterranean, have been identified in the Kalithea Bay section. The position of these events at Kalithea Bay and a correlation to the Vrica section is shown in Figure 6. The data for the Vrica section are for the ostracodes from Colalongo \& Pasini (1980) and Aguirre \& Pasini (1985), and for the foraminifera from Zijderveld et al. (1991) and Lourens et al. (1996, 1998). The events are all first occurrences (FO) and they are in stratigraphical order: FO of Globorotalia inflata (planktic foraminifera) in sample 14,1; FO of Cytheropteron rotundatum (ostracode) and FO of Hyalinea balthica (benthic foraminifera) both in sample 18,C4; FO of abundant Neogloboquadrina pachyderma (sinistral form, s) in sample 19,A3; FO of Cytheropteron alatum (ostracode) in sample 19,A4; and FO of Pedicythere polita (ostracode) and Buntonia textilis (ostracode) in sample 24,2. Two of the species noted above, namely the ostracodes $C$. rotundatum and $B$. textilis, have later been observed in deposits referred to the Early

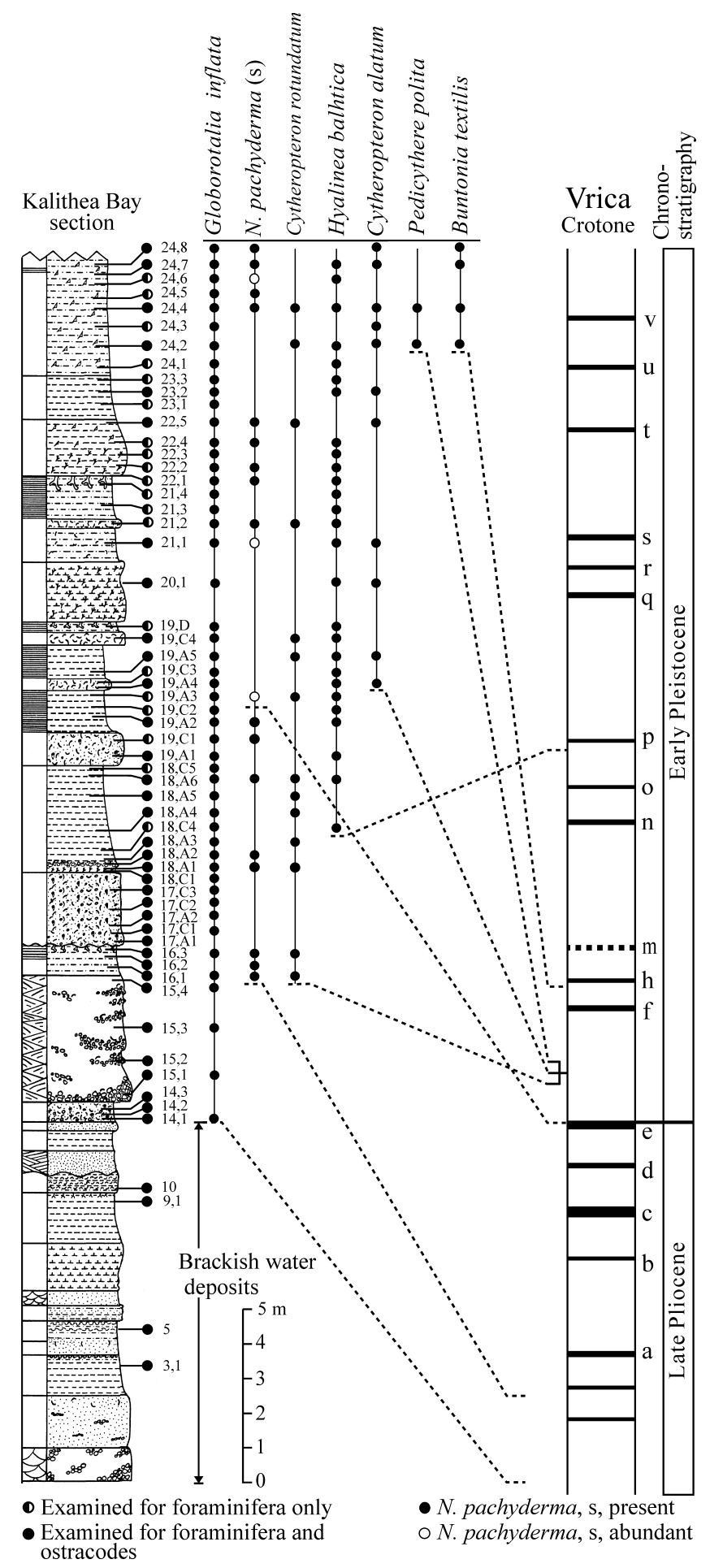

Fig. 6. Correlation between the Kalithea Bay section and the PliocenePleistocene boundary section at Vrica/Crotone, Italy, by means of ostracodes (Cytheropteron rotundatum, Cytheropteron alatum, Pedicythere polita and Buntonia textilis), benthic foraminifera (Hyalinea balthica) and planktic foraminifera (Globorotalia inflata and Neogloboquadrina pachyderma, s, left coiled). Note that the Hyalinea balthica event is strongly diachronous relative to the other ostracode and foraminifera events. Ages are from Lourens et al. (1996). 
Pliocene (Bossio et al., 1989; Barra et al., 1998). However, they have not been observed in Late Pliocene deposits and their recurrence in the Early Pleistocene seem to be useful biostratigraphic events.

Note that the FO of $H$. balthica is strongly diachronous relative to the $\mathrm{FO}$ of, in particular, C. alatum, N. pachyderma (s), $P$. politas and B. textilis.

\section{Comparison of calcareous nannofossil, ostracode and foraminifera biostratigraphy}

Several of the calcareous nannofossil events used to date the Kalithea Bay section have also been recognized in the Vrica section (e.g. Backman et al., 1983; Zijderveld et al., 1991; Rio et al., 1996; Lourens et al., 1996, 1998). It is therefore possible to compare the ostracode and foraminifera correlations between the two sections with correlations based on calcareous nannofossils.

The comparison shows that most ostracode and foraminifera events are diachronous relative to the calcareous nannofossil events (Fig. 7). The only synchronous event is the first occurrence of the benthic foraminifera $H$. balthica. As noted earlier, the calcareous nannofossil events can be regarded as virtually synchronous throughout the Mediterranean region. The diachroneity is therefore probably due to a relative delay in the appearance of the ostracodes and foraminifera at Kalithea Bay.

We interpret the delay to be the result of palaeoenvironmental differences between the two sites. The Vrica section represents a uniform bathyal setting with an estimated water depth of $500-800 \mathrm{~m}$ (Colalongo et al., 1980), in contrast to the transgressive, more shallow water setting at Kalithea Bay, where only the uppermost units were deposited at bathyal depths. The investigated ostracodes are basically deep-water species living on the outer shelf and the upper slope (Puri et al., 1969; Breman, 1975; Bonaduce et al., 1976), and their first occurrence in the Kalithea Bay section was probably delayed because of the nearshore environment that persisted here during the deposition of the lower part of the section. This explanation may also account for the delay in the first appearance of $N$. pachyderma (s) at Kalithea Bay, since this species usually is connected to open ocean environments. However, the delay may also be the result of a general late arrival of $N$. pachyderma (s) in the eastern Mediterranean, as documented by ODP site 969 south of Crete and ODP site 967 south of Cyprus. At both of these sites, N. pachyderma (s) first appears shortly below the Plio-Pleistocene boundary, and about 120000 years after its first occurrence at Vrica (Lourens et al., 1998). The apparent synchronous first occurrence of H. balthica at Kalithea Bay and Vrica may probably be related to a wider bathymetrical range of this species as it occurs in both neritic and epibathyal environments (Sprovieri \& Hasegawa, 1990). However, it should be noted that the $H$. balthica event is not always a reliable datum plane. It has been shown to be diachronous in several cases even within the Mediterranean (Lourens et al., 1998). Finally, we would like to point out that first occurrence of $G$. inflata in the Kalithea Bay section coincides with the base of the marine sequence, and clearly does not represent the true first appearance of the species in the area.
Biostratigraphy and age of the brackish water units

The brackish water units 1-13 are difficult to date. They contain a low diversity foraminifera and ostracode fauna and calcareous nannofossils are absent. The foraminifera are dominated by Ammonia beccarii, while the ostracodes are dominated by Cyprideis torosa, Loxoconcha phaseola and Leptocythere peterseni. Since the Late Pliocene, C. torosa has spread over vast areas in environments with anomalous salinity. L. peterseni is known from Late Pliocene deposits on the Island of Kos and from the Damatria Formation on Rhodes (Mostafawi, 1989a, b). Related faunas have been found in brackish water and hypersaline deposits from both the Damatria and Kritika formations and they have traditionally been referred to the Late Pliocene.

\section{BIOSTRATIGRAPHIC REMARKS ON SOME EARLY PLEISTOCENE OSTRACODES}

As shown above, the distribution of ostracodes are often linked to facies and they are of problematic value in detailed correlations between sections from different palaeoenvironmental settings. However, many species may still be good biostratigraphic markers on a broader scale, for example as general indicators of a Pleistocene age. This is probably the case for C. alatum and $P$. polita discussed above (see also Colalongo \& Pasini, 1988; Colalongo et al., 1990). However, several other species recognized in the Kalithea Bay section are considered to be useful Pleistocene markers. Tenedocythere prava and Callistocythere crispata appearing in unit 14 are both believed to indicate a Pleistocene age in Italy and Greece (Sissingh, 1972, 1976, 1982; Ruggieri, 1980; Malz \& Jellinek, 1984; Mostafawi, 1986, 1989a; Bonaduce et al., 1986). Moreover, in the Mediterranean, T. prava and C. crispata are only known from Emilian and younger deposits (Bonaduce et al., 1986, Mostafawi, 1989a). Also Polycope demulderi, first appearing in unit 14, and Pontocythere rubra, first appearing in unit 15 , are Pleistocene to Recent species (Sissingh, 1972; Colalongo \& Pasini, 1980; Athersuch, 1982; Malz \& Jellinek, 1984).

\section{BIOSTRATIGRAPHY AND AGE OF OTHER PLIO-PLEISTOCENE SECTIONS ON RHODES}

The ostracode and foraminifera faunas in the upper part (unit 24) of the Kalithea Bay section compare closely to those of the nearby section of Lindos Bay clay at Vasfi, and the two deposits are probably contemporaneous. The occurrence of $H$. balthica, in combination with a characteristic fauna of pteropods, indicates that the Lindos Bay clay in the section at Cape Vagia roughly is of the same age, too.

Only two sections referred to the Kritika Formation have been examined in some detail so far, namely the type section at Kritika and a section exposed at Ladiko about $5 \mathrm{~km}$ south of the Kalithea Bay section (Fig. 3). Sissingh (1972) examined the ostracodes in a few samples from the Kritika section. He placed the section, tentatively, in the Late Pliocene in his Cyprideis torosa zone, because of the occurrence of C. torosa. However, as noted above, this species is common in brackish water environments from the Late Pliocene to Present, and it is of little stratigraphical value. Hajjaji et al. (1998) examined a larger number of samples from the same section. They accepted the age assignment of Sissingh (1972) notwithstanding the presence of 
Integrated microbiostratigraphy of the Plio-Pleistocene, Rhodes (Greece)

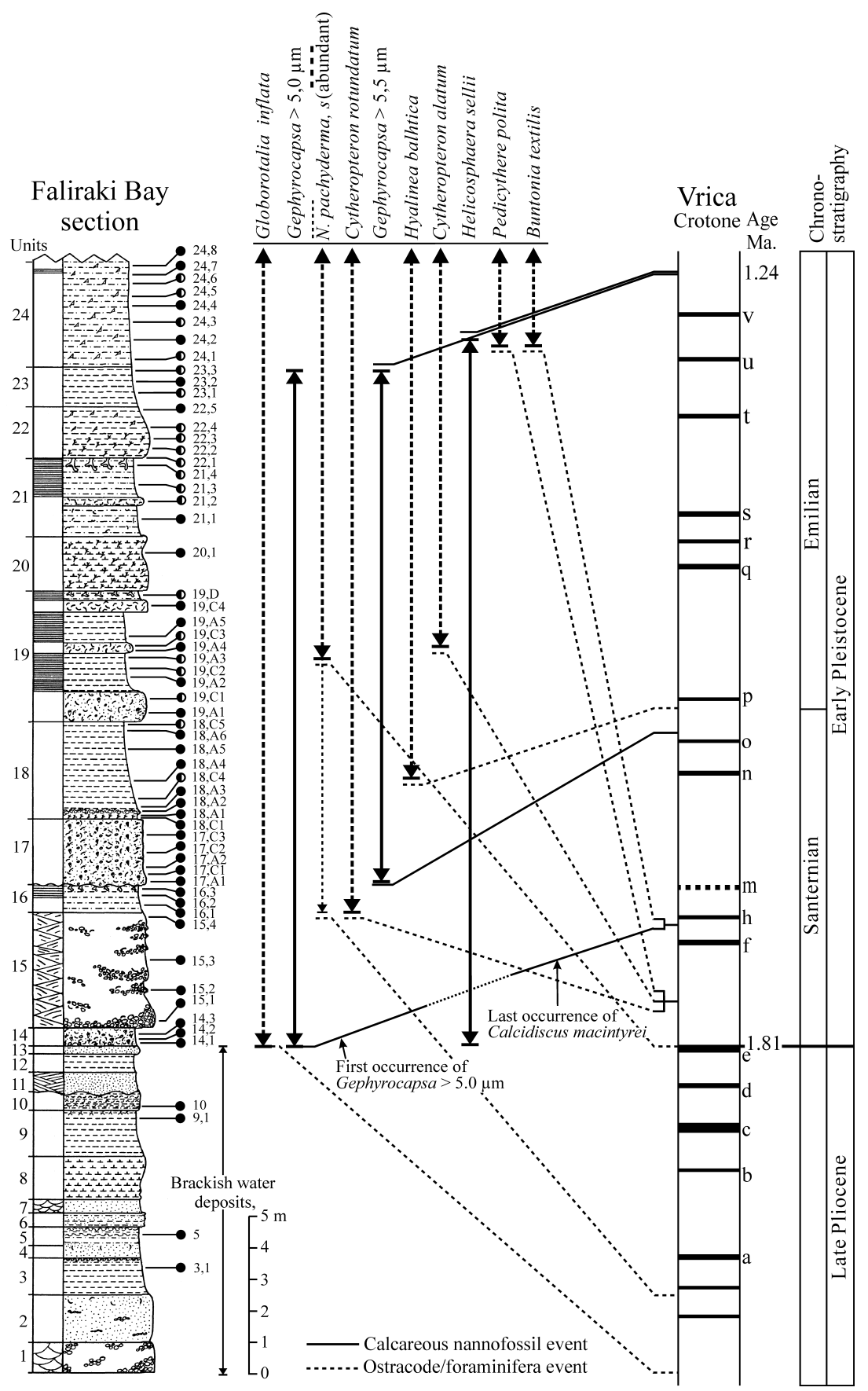

Fig. 7. Correlation between the Kalithea Bay section and the Pliocene-Pleistocene boundary section at Vrica/Crotone, Italy, by means of ostracodes (Cytheropteron rotundatum, Cytheropteron alatum, Pedicythere polita and Buntonia textilis), benthic foraminifera (Hyalinea balthica), planktic foraminifera (Globorotalia inflata and Neogloboquadrina pachyderma, s, left coiled) and calcareous nannofossils (FO of Gephyrocapsa spp. $>5.0$ um, FO, and LO of Gephyrocapsa ssp. $>5.5 \mu \mathrm{m}$ and LO of Helicosphaera sellii). The position of the first occurrence of Gephyrocapsa spp. $>5.0 \mu \mathrm{m}$ has not been examined in the Vrica section. Instead, as an alternative event, we used the last occurrence of Calcidiscus macintyrei. These two events are almost simultaneous in the Mediterranean (de Keanel et al. 1999). C. macintyrei has not been observed in the Kalithea Bay section due to unfavorable brackish water conditions during the deposition of the lower part. Note that the datum events of ostracodes and foraminifera are diachronous as compared to the calcareous nannofossil events, except for Hyalinea balthica. Ages are from Lourens et al. (1996).

the ostracodes $T$. pravaand $P$. polita. These species are also present in the Kalithea Bay section, and they have, as discussed above, never been observed in sediments older than Quaternary. The Kritika section is, therefore, most likely of Pleistocene age. However, its exact age relative to the Kalithea Bay section can only be established with further investigations, preferably of calcareous nannofossils.

The section at Ladiko was examined by Broekman (1974), who found a moderately rich fauna of ostracodes and foraminifera. Species of biostratigraphic value were scarce, and 
only the ostracode Aurila calciplena may have some significance. It indicates that the greater part of the section may be of Pliocene age.

Thus, four out of five marine Plio-Pleistocene sections examined so far can be referred to the Pleistocene. Only the section at Ladiko may possibly be Late Pliocene.

\section{CONCLUSIONS}

The lower part of the Kalithea Bay section consists of alternating coarse- and fine-grained sediments with scattered brackish water molluscs representing a paralic environment. The paralic succession is overlain by fully marine sediments which gradually become more fine grained upwards, and the uppermost clayey beds were deposited in an upper bathyal environment. The deep-water deposits are unconformably overlain by a coarsegrained calcarenite, indicating a return to shallow water conditions. The paralic and shallow water marine deposits are referred to the Kritika Formation, whereas the deep-water deposits and the overlying calcarenite are referred to the Lindos Bay clay and Cape Arkhangelos calcarenite of the Rhodes Formation.

Calcareous nannofossil biostratigraphy of the Kritika Formation and Lindos Bay clay indicates that the marine part of the succession is of Early Pleistocene age. Using the astronomically calibrated ages of de Keanel et al. (1999), the base of the marine section can be dated to approximately $1.60 \mathrm{Ma}$, while the age of the top is about $1.00 \mathrm{Ma}$. All biostratigraphic zones seem to be present and there are no indications of major hiati within the investigated interval.

The Kalithea Bay section is rich in ostracodes and foraminifera and we have recognized several species, which previously have been used as biostratigraphic markers in the PlioPleistocene deposits on Rhodes. Seven of these events, together with some of the most important calcareous nannofossil events, have also been recognized in the Plio-Pleistocene boundary stratotype at Vrica, southern Italy. It is therefore possible to correlate the two sections using all three groups and to compare the results.

The comparison shows that the ostracode and foraminifera events are diachronous relative to the calcareous nannofossil events except for the first occurrence of the benthic foraminifera $H$. balthica. As calcareous nannofossil events are regarded to be virtually synchronous within the Mediterranean region, we conclude that the diachroneity is due to a relative delay in the appearance of ostracodes and foraminifera at Kalithea. We suggest that the delay is the result of differences in palaeobathymetry and palaeoenvironment between the two sections.

Thus, the investigated ostracodes and foraminifera are linked to facies and of problematic value in detailed correlations between sections from different palaeoenvironmental settings. However, most of these species may still be good biostratigraphic markers on a broader scale, for example as general indicators of a Pleistocene age. Hence, in this study, we have compared the ostracode and foraminifera faunas of the Kalithea Bay section with faunas described from other marine PlioPleistocene sections on Rhodes. The results suggest that most of these sections are of Early Pleistocene age, including the type section of the Kritika Formation, which previously has been regarded to be Late Pliocene.

\section{ACKNOWLEDGEMENTS}

We thank K. Rosendal for processing the micropalaeontological samples and R. Bromley, E. Håkansson and S.B. Andersen for critical reviews of the manuscript. R. Bromley and E. Håkansson are also thanked for their comments during a field-visit to the Kalithea Bay section. We would also like to thank N. Spjeldnæs, whose inspiring field-courses introduced us to the geology of Rhodes, in general and to the Kalithea Bay section in particular. Finally, we are very grateful to the Institute of Geology and Mineral Explorations, Athens, for permission to do fieldwork on Rhodes.

\section{Manuscript received 23 August 2000 \\ Manuscript accepted 10 July 2001}

\section{REFERENCES}

Aguirre, E. \& Pasini, G. 1985. The Pliocene-Pleistocene Boundary. Episodes, 8: 116-120.

Athersuch, J. 1982. Some ostracod genera formerly of the Family Cytherideidae Sars. In Bate, R. H., Robinson, E. \& Sheppard, L. M. (Eds), Fossil and Recent Ostracods, 231-275. Ellis Horwood, London.

Backman, J. \& Shackleton, N. J. 1983. Quantitative biochronology of Pliocene and early Pleistocene calcareous nannoplankton from the Atlantic, Indian, and Pacific oceans. Marine Micropaleontology, 8: 141-171.

Backman, J., Shackleton, N. J. \& Tauxe, L. 1983. Quantitative nannofossil correlation to open ocean deep-sea sections from Plio-Pleistocene boundary at Vrica, Italy. Nature, 304: 156-158.

Barra, D., Bonaduce, G. \& Sgarella, F. 1998. Paleoenvironmental bottom water conditions in the early Zanclean of the Capo Rossello area (Agrigento, Sicily). Bollettino della Società Paleontologica Italiana, 37: 61-98.

Benda, L., Meulenkamp, J. E. \& van der Weerd, A. 1977. Biostratigraphic correlations in the Eastern Mediterranean Neogene. 3. Correlations between mammal, sporomorphs and marine microfossil assemblages from the Upper Cenozoic of Rhodes, Greece. Newsletters on Stratigraphy, 6: 117-130.

Black, M. \& Barnes, B. 1961. Coccoliths and discoasters from the floor of the South Atlantic Ocean. Journal of the Royal Microscopical Society, 80: 137-147.

Bonaduce, G., Ciampo, G. \& Masoli, M. 1976. Distribution of Ostracoda in the Adriatic Sea. Pubblicazioni della Stazione Zoologica di Napoli, $\mathbf{4 0}$ suppl.1: 1-304.

Bonaduce, G., Ruggieri, G. \& Russo, A. 1986. The genus Tenedocythere (Ostracoda, Podocopida) of the Mediterranean Miocene to Recent especially from Italy. Bolletino della Società Paleontologica Italiana, 23: $515-543$.

Bossio, A., Guelfi, F., Mazzei, R., Monteforti, B. \& Salvatorini, G. 1989. Studi sul Neogene e Quaternario della Penisola salentina III Stratigrafia del Pozzo Poggiardo ( ${ }^{\circ}$ 54, PS 1490/3). Quaderni di ricerche del Centro Studi geotecnici e d'Ingegneria. Atti del Convegno sulle conoscenze geologiche del territorio salentino. Lecce, 12 Dicembre, 11: 55-87.

Breman, E. 1975. The Distribution of Ostracods in the Bottom Sediments of the Adriatic Sea. Academisch Proefscrift, Vrije Universiteit Te Amsterdam.

Broekman, J. A. 1973. Sedimentary structures and paleoecology of the Pliocene Kritika Formation in a section near Kalithies (Rhodes, Greece). Proceedings of the Koninklijke Nederlandse Akademie van Wetenschappen, Series B, 76: 423-445.

Broekman, J. A. 1974. Sedimentation and paleoecology of Pliocene lagoonal-shallow marine deposits on the island of Rhodos (Greece). Utrecht Micropaleontological Bulletins, 8: 1-142 
Castradori, D. 1993. Calcareous nannofossil biostratigraphy and biochronology in eastern Mediterranean deep-sea cores. Rivista Italiana Paleontologia e Stratigrafia, 99: 107-127.

Colalongo, M. L. \& Pasini, G. 1980. La ostracodfauna plio-pleistocenica della sezione Vrica in Calabria (con considerazioni sul limite Neogene/ Quaternario). Bolletino della Società Paleontologica Italiana, 19: 44-126.

Colalongo, M. L. \& Pasini, G. 1988. Ostracofauna plio-pleistocenica batiale rinvenuta nel Pozzo 654A dell'ODP Leg 107 (Mare Tirreno occidentale). Bolletino della Società Paleontologica Italiana, 27: 277-289.

Colalongo, M. L., Pasini, G. \& Sartoni, S. 1980. Remarks on the Neogene/Quaternary boundary and the Vrica section. Preprint, 26th International Geological Congress, Section S. 08: Paris, 1980.

Colalongo, M. L., Pasini, G., Poluzzi, A. \& Sprovieri, R. 1990. Relationship between the benthic foraminifers and the ostracodes in the Pliocene-Pleistocene Tyrrhenian deep-sea record (ODP Leg 107, site 654). In Kastens, K. A. \& Mascle, J. (Eds), Proceedings of the Ocean Drilling Program, Scientific Results (Ocean Drilling Program), 107: 479-493. College Station, Texas.

Di Stefano, E. 1998. Calcareous nannofossil quantitative biostratigraphy of holes 969E and 963B (Eastern Mediterranean). In Robertson, A. H. F., Emeis, K.-C., Richter, C. \& Camerlenghi, A. (Eds), Proceedings of the Ocean Drilling Program, Scientific Results (Ocean Drilling Program), 160: 99-112. College Station, Texas.

Di Stefano, E. \& Sprovieri, R. 1990. Calcareous plankton biostratigraphy of ODP Leog 107 Site 651 uppermost Pliocenelowermost Pleistocene. Memoire della Società Geologica Italiana, 44: $157-165$.

Ellis, C. H. \& Lohman, W. H. 1979. Neogene nannoplankton biostratigraphy in eastern Mediterranean deep-sea sediments. Marine Micropaleontology, 4: 61-84.

Hajjaji, M., Bodergat, A. M., Moissette, P., Prieur, A. \& Rio, M. 1998. Signification écologique des assiciations d'ostracodes de la coupe de Kritika (Pliocène supérieur, Rhodes, Grèce). Revue de Micropaléontologie, 41: 211-233.

Hanken, N. M., Bromley, R. G. \& Miller, J. 1996. Plio-Pleistocene sedimentation in coastal grabens, north-east Rhodes, Greece. Geological Journal, 31: 271-296.

Hansen, K. S. 1999. Development of a prograding carbonate wedge during sea level fall: Lower Pleistocene of Rhodes, Greece. Sedimentology, 46: 559-576.

Kovacs, E. \& Spjeldnæs, N. 1999. Pliocene-Pleistocene stratigraphy of Rhodes, Greece. Newsletters on Stratigraphy, 37: 191-208.

Lourens, L. J., Hilgen, F. J., Raffi, I. \& Vergnaud-Grazzini, G. 1996. Early Pleistocene chronology of the Vrica section (Calabria, Italy). Paleoceanography, 11: 797-812.

Lourens, L. J., Hilgen, F. J. \& Raffi, I. 1998. Base of large Gephyrocapsa and astronomical calibration of early Pleistocene sapropels in Site 967 and Hole 969D: solving the chronology of the Vrica section (Calabria, Italy). In Robertson, A. H. F., Emeis, K.-C., Richter, C. \& Camerlenghi, C. (Eds), Proceedings of the Ocean Drilling Program, Scientific Results (Ocean Drilling Program), 160: 191-197. College Station, Texas.

Løvlie, R., Støle, G. \& Spjeldnæs, N. 1989. Magnetic polarity stratigraphy of Pliocene-Pleistocene marine sediments from Rhodos, eastern Mediterranean. Physics of the Earth and Planetary Interiors, 54: 340-352.

Malz, H. \& Jellinek, T. 1984. Marine Plio-Pleistocän-Ostracoden von SE-Lakonien (Peloponnes, Griechenland). Senckenbergiana Biologica, 65: $113-167$.

Meulenkamp, J. E., de Mulder, E. F. J. \& van der Weerd, A. 1972. Sedimentary history and paleogeography of the Late Cenozoic of the island of Rhodos. Zeitschrift Deutsche geologische Gesellschaft, 123: 541-553.

Moissette, P. \& Spjeldnæs, N. 1995. Plio-Pleistocene deep-water bryozoans from Rhodes, Greece. Palaeontology, 38: 771-799.

Mostafawi, N. 1986. Pleistozäne Ostracoden aus der NikolaosFormation von Ost-Kos, Griechenland. Senckenbergiana lethaea, 67: 275-303.

Mostafawi, N. 1989a. Limnische und marine Ostracoden aus dem Neogen der Insel Rhodos (Griechenland). Courier Forschungsinstitut Senckenberg, 113: 117-157.
Mostafawi, N. 1989b. Neogene Ostracoden von Chersonisos und Vrysses (Kreta, Griechenland). Neues Jahrbuch für Geologie und Paläontologie, Abhandlungen, 178: 183-201.

Mutti, E., Orombelli, G. \& Pozzi, R. 1970. Geological studies on the Dodecanese Islands (Aegean Sea). Annales géologiques des Pays Helléniques, 22: 79-226

Müller, C. 1978. Neogene calcareous nannofossils from the Mediterranean - Leg 42a of the Deep Sea Drilling Project. In Hsü, K. J. \& Montadert, L. (Eds), Initial Reports of the Deep Sea Drilling Project 42: 727-751. US Printing Office, Washington DC.

Müller, C. 1990. Nannoplankton biostratigraphy and paleoenvironmental interpretations from the Tyrrhenian Sea, ODP Leg 107 (Western Mediterranean). In Kastens, K. A. \& Mascle, J. (Eds), Proceedings of the Ocean Drilling Program, Scientific Results (Ocean Drilling Program), 107: 495-511. College Station, Texas.

Orombelli, G. \& Montanari, C. 1967. Geological Studies of the Dodecanese Islands (Aegean Sea) 6. The Calabrian of the Island of Rhodes (Greece). Bolletino della Società Paleontologica Italiana, 86: 103-113.

Puri, H. S., Bonaduce, G. \& Gervasio, A. M. 1969. Distribution of Ostracoda in the Mediterranean. In Neale, J. W. (Ed.), The Taxonomy, Morphology and Ecology of Recent Ostracoda, 356-411. Oliver \& Boyd, Edinburgh.

Raffi, I. \& Rio, D. 1979. Calcareous nannofossil biostratigraphy of DSDP Site 132 - Leg 13 (Tyrrhenian Sea - Western Mediterranean). Rivista Italiana Paleontologia e Stratigrafia, 85: 127-172.

Rio, D., Raffi, I. \& Villa, G. 1990. Pliocene-Pleistocene calcareous nannofossil distribution patterns in the western Mediterranean. In Kastens, K. A. \& Mascle, J. (Eds), Proceedings of the Ocean Drilling Program, Scientific Results (Ocean Drilling Program), 107: 479-493. College Station, Texas.

Rio, D., Backman, J. \& Raffi, I. 1996. Calcareous nannofossil biochronology and the Pliocene-Pleistocene boundary. In van Couvering, J. A. (Ed.), The Neogene-Quaternary boundary. World and Regional Geology, 9: Cambridge University Press, New York.

Ruggieri, G. 1980. Sulla distribuzione stratigrafica di alcuni ostracodi Pleistocene italiano. Bolletino della Società Paleontologica Italiana, 19: $127-135$.

Sblendorio-Levy, J. \& Howe, R. W. 1998. Calcareous nannofossil biostratigraphy of site 953, Canary basin, Northeastern North Atlantic. In Weaver, P. P. E. \& Schmincke, H.-U. (Eds), Proceedings of the Ocean Drilling Program, Scientific Results (Ocean Drilling Program), 157: 83-96. College Station, Texas.

Schmidt, R.R. 1973. A calcareous nannoplankton zonation for upper Miocene-Pliocene deposits from the southern Aegean area, with a comparison to Mediterranean stratotype localities. Proceedings of the Koninklijke Nederlandse Akademie van Wetenschappen, Series B, 76: 287-310.

Sissingh, W. 1972. Late Cenozoic Ostracoda of the South Aegaean Island Arc. Utrecht Micropaleontological Bulletins, 6.

Sissingh, W. 1976. Tentative middle Miocene to Holocene ostracode biostratigraphy of the central and Eastern Mediterranean Basin, I and II. Proceedings of the Koninklijke Nederlandse Akademie van Wetenschappen, Series B, 79: 270-299.

Sissingh, W. 1982. Ecostratigraphical outline history of the Late Cenozoic ostracode fauna of the Central and Eastern Mediterranean Basin. Proceedings of the Koninklijke Nederlandse Akademie van Wetenschappen, Series B, 85: 299-322.

Spjeldnæs, N. \& Moissette, P. 1997. Celeporid (bryozoan) thickets from the Upper Pliocene of the island of Rhodes, Greece. In James, N. P. \& Clarke, J. A. D. (Eds), Cool-Water Carbonates. SEPM Special Publications, 56: 262-270.

Sprovieri, R. \& Hasegawa, S. 1990. Plio-Pleistocene benthic foraminifer stratigraphic distribution in the deep-sea record of the Tyrrhenian Sea (ODP LEG 107). In Kastens, K. A. \& Mascle, J. (Eds), Proceedings of the Ocean Drilling Program, Scientific Results (Ocean Drilling Program), 107: 429-459. College Station, Texas.

Staeker, T. S. 1998. Quantitative calcareous nannofossil biostratigraphy of Pliocene and Pleistocene sediments from the Erastosthenes Seamont Region in the Eastern Mediterranean. In Robertson, A. H. F., Emeis, K.-C., Richter, C. \& Camerlenghi, A. (Eds), 
Proceedings of the Ocean Drilling Program, Scientific Results (Ocean Drilling Program), 160: 83-98. College Station, Texas.

Young, J. 1990. Size variation of Neogene Reticulofenestra coccoliths from Indian Ocean DSDP Cores. Journal of Micropalaeontology, 9: $71-86$.

Young, J. R. \& Bown, P. R. 1997. Cenozoic calcareous nannoplankton classification. Journal of Nannoplankton Research, 19: 36-47.

Zijderveld, J. D. A., Hilgen, F. J., Langereis, C. G., Verhallen, P. J. J. M.

\& Zachariasse, V. J. 1991. Integrated magnetostratigraphy and biostratigraphy of the upper Pliocene-lower Pleistocene from the Monte Singa and Crotone areas in Calabria, Italy. Earth and Planetary Science Letters, 107: 697-714.

de Keanel, E., Siesser, W. G. \& Murat, A. 1999. Pleistocene calcareous nannofossil biostratigraphy and the Western Mediterranean sapropels, sites 974 to 977 and 979. In Zahn, R. \& Klaus, A. (Eds), Proceedings of the Ocean Drilling Program, Scientific Results (Ocean Drilling Program), 161: 479-493. College Station, Texas. 